\title{
Sectarianism and Governance in Syria Raymond Hinnebusch
}

What is the relationship between sectarianism and governance in the Middle East and North Africa (MENA)? How far can the dominant outcomes of the Arab Uprisings--failed states and new harsher forms of authoritarianism, rather than democracy-be attributed to the sectarian wave that followed the Uprising? Does sectarianism obstruct democratization, empower authoritarianism and, in extreme cases, contribute to state failure?

Sectarianism is defined as identification with a religious community that sharply emphasizes boundaries with the "Other," particularly when politicized and even more so when involving claims of monopoly over religious truth. ${ }^{1}$ Governance denotes the strategies of ruling elites and the state institutions they govern through, but also, when these fail, forms of non-state governance. Why should sectarianism be a problem for governance? Rustow (1970) famously argued that governance is facilitated by a shared national identity within the state and that democracy, in particular, depends on this to keep competition over lesser issues peaceful. Sectarianism, on the other hand, seems associated with strong particularistic solidarity within a sub-state group and potential enmity toward the "Other," hence, may be politically divisive and lend itself to exclusionary governance practices. Yet, as Peter Sluglett (2016: 44-45) observed, the role of sectarianism varies greatly in different contexts and, in MENA, far from having a uniform impact on politics, has coexisted with a variety of governance scenarios. This paper makes a start at systematically uncovering how variations in sectarianism differ in their impact on governance and how variations in the latter have a variable impact on sectarianism, providing an essential first step for further research.

\section{The Research problematic: Toward Understanding the Sectarianism-Governance Nexus}

A starting point for examining the inter-relation of sectarianism and governance is to look at the evidence from large-n statistical studies. While there are none on sectarianism, there are many on identity heterogeneity and its affect particularly on

\footnotetext{
${ }^{1}$ In the Syrian context sectarianism refers to both inter-Islamic differences (Alawi, Shia, Sunni etc.) and Muslim-Christian differences.
} 
democracy. Thus, Gerring, Zarecki and Hoffman's (2016) survey of twenty studies on identity-specifically ethno-linguistic diversity--found a somewhat negative relation with democracy. More relevant are studies of religious diversity, which, several scholars argue, is more of a deterrent to democracy since the rival claims of ethnic groups (for autonomy, a fair share of resources) can more easily be compromised than contradicting divinely sanctioned religious edicts (Brubaker 2015), insofar as religious groups makes such claims in the public sphere; and, when the state sponsors one religion in multi-religious societies, it excludes others, possibly requiring authoritarian repression. Yet of 8 large-n studies of the impact of religious diversity on democracy surveyed by Gerring, Zarecki and Hoffman (2016) one finds a negative, one a positive and the rest no effect while their own study showed it reduces the chances of democratization by only $8.4 \%$.

This inconclusive picture is arguably an artefact of simple statistical associations that do not control for variables intervening between sectarianism and governance, such as levels of modernization or political agency that may alter the relationship. The studies also disguise variations in the main variables e.g., different kinds of sectarianism that may differentially impact on governance and variations in governance, e.g. differences in kinds of democratic and authoritarian regimes, which may matter for how governance impacts sectarianism.

To move forward, the paper begins by bringing together relevant literatures on identity politics that explore sectarianism and it impact on governance, with Weberian literature used to explore the impact of governance on sectarianism, in the process unpacking the key variables and identifying intervening ones. From this is derived a framework of analysis specifying the key relevant factors and their possible interrelations.

The Syrian case is then used to illustrate how the framework helps us to explore the complex relations among the variables and how they came together in different concrete historical-contingent configurations in Syria. ${ }^{2}$ Syria is a valuable test case both because of the sharp differences among scholars on the importance of sectarianism in its politics ${ }^{3}$ and also because it has experienced substantial variation in both

\footnotetext{
2 While not based on new empirical research, the paper draws extensively on existing knowledge of Syria, including Arabic sources, and the most recent studies on sectarianism in the post-2011 uprising (Abboud 2016, Kerr and Larkin 2015; Balanche 2018; Hinnebusch and Imady, 2018).

${ }^{3}$ Compare, for example, Van Dam (1981) and Van Dusen (1975).
} 
sectarianism and governance. The latter allows a comparative exploration of the role of sectarianism in three quite different contexts: an episode of failed democratization in which sectarianism played little role; a period of authoritarianism, in which sectarianism played some role; and a second failure of democratization, leading to civil war, in which sectarianism played a salient role. While such a single case study does not allow us to test some key questions (such as whether different distributions of sectarian groups determine governance possibilities), a longitudinal study of one country does allows us to at least explore alternative causal explanations for the changing salience of sectarianism over time in a case that is "iconic" for debates over sectarianism. Does the evidence validate the approach of "primordialists" who stress societal inheritances or "instrumentalist" explanations stressing politics? The paper's conclusion summarizes the findings and puts the case in the context of these rival approaches to identity politics (Varshney 2009).

\section{Identity and Regime Trajectories: How Does Sectarianism Impact Governance?}

Sectarianism affects governance, not by itself, but in conjunction with other factors that together make up the identity pattern of a society. These variables are discussed below. First, however, it is necessary to unpack sectarianism and distinguish its variant kinds.

The kinds of Sectarianism and its intensity:

Multi-sectarian societies do not experience uniform levels of inter-sectarian enmity and, indeed, amity is not uncommon. Such variations may, in part, be explained by differences in the kind of sectarianism, which is far from a uniform phenomenon. Building on Haddad (2011), sectarianism can be seen as varying along a continuum of intensity--from "banal" to "instrumental" to "militant"--and these might be expected to have quite varying impacts on amity/enmity, hence on governance. Banal sectarianism, while "ascriptive" - one is born into and socialized into a sect--is largely non-politicized and compatible with sectarian co-existence and the simultaneous embrace of a broader state identity or political ideology. Instrumental sectarianism is politicized, a method of group competition for scarce resources or power but is not about conflicting religious doctrines. Political entrepreneurs may mobilize sects for normally peaceful resource competition, as in consociational versions of democracy (Lebanon) but also authoritarian elites may manipulate sectarian identities (from above) to co-opt clients 
and/or to divide and rule identity-diverse populations. Militant sectarianism, interpreting Brubaker (2015), is not only highly politicized, but also "fundamentalist"-concerned with doctrinal and behavioural purity. It typically asserts a monopoly of religious truth, denounces those who do not accept this truth as infidel (e.g. by takfiris), and is often willing to use violence against "apostates." There is outbidding in hostility within the sect toward other sects; hyper-commitment by activists to the cause, e.g. embrace of martyrdom; and trans-national mobilization (across state boundaries). These distinctions are ideal types whose features may coexist and overlap in concrete situations; thus, instrumental sectarianism could turn violent while militant sectarianism could be instrumentalized in power competitions. The distribution of sectarian intensity in a society matters for its salience: for example, the more banal sectarianism dominates, the less will sectarianism be salient and if militant sectarianism is confined to marginal groups its salience may still be low; if instrumental sectarianism is widespread, its salience would perhaps be medium and the dominance of militant sectarianism would make for high sectarian salience.

\section{Sectarianism in the identity pattern of societies}

A series of other factors are likely to affect the salience of sectarianism in a country's identity pattern. First, it is affected by the degree of polarization among sects, which in turn may be related to the distribution of sectarian groups in society. As Merkel and Weiffen (2012) found, polarization among identities determined levels of intercommunal $^{4}$ conflict, and it was more likely when 2-3 large groups were evenly balanced in size, communal consciousness and mobilization than in societies fragmented into many small groups or with a large majority and several smaller minorities. The more polarization, the more salient sectarianism.

Second the, identity pattern is affected by the relative power of other identities that compete with sectarianism. In MENA these include sub-state identities (tribe, region, class); supra-state identities, Pan-Arabism and Pan-Islam; and state (territorial) nationalism. Two identities have particular potential to subsume sectarianism in a wider identity: first, territorial nationalism (especially if civic) is inclusionary and hence could subsume other identities; it is relatively weak in MENA (Scarritt 2005), however, the minority of states with long historic roots and fixed territorial borders (Egypt,

\footnotetext{
${ }^{4}$ Communal identities usually denotes sub-state identities, specifically ethnic and sectarian groups.
} 
Tunisia) have a greater potential to foster it than states with recent externally imposed arbitrary borders, as in the Levant. Second, because the MENA region and especially the Arab world is relatively linguistically homogeneous $-84 \%$ of states have a dominant ethno-linguistic identity-Arab, Turkish and Iranian ethno-nationalisms could be the basis of national integration.

Third, modernization may shift the balance of identities. Thus, social mobilization (e.g. spread of modern education) potentially allows a broadening toward more inclusive national identities congruent with the state (Deutsch 1961) and banal sectarianism, in particular, may well be subsumed in such wider loyalties. Moreover, the typical increase in class inequalities during early capitalist development increases class consciousness; as the new middle and working classes become politicized, class may overshadow sectarian differences as the dominant basis of mobilization; thus, in the 1958 Iraqi revolution, Sunni and Shia middle and lower classes were brought together in common class struggle against the ruling oligarchy. Simultaneously, however, since modernization increases competition for scarce resources among groups, if access to state resources becomes organized by wasta-personal connections--based on sectarian clienteles, it could shift banal to instrumental sectarianism. Since both tendencies may operate simultaneously, the inter-relation of horizontal (class) and vertical (communal) cleavages shapes outcomes, as a venerable body of literature has shown. Thus, if class and communal cleavages overlap and reinforce each other (in its purest form one communal group constituting the upper class and another the lower class) polarizing conflict is likely to result; but where class and communal cleavages cross-cut and dilute each other, they mute conflict, facilitating more inclusive national identities (Grove 1987; Gubler and Selway 2012). More generally, there are always multiple competing identities-certainly so in MENA--and individuals may hold several simultaneously, which works against hardening into irreconcilable identity blocs.

Fourth, political agency matters. Social structure does not pre-determine outcomes, especially as the multiplicity and plasticity of identities allows considerable scope for political entrepreneurs to instrumentalize identities--politicizing some while marginalizing others in order to mobilize support in power struggles. They may go further and engage in securitization--representing ones identity as existentially threatened by the "Other" (Malmvig 2015). Whether agents choose to instrumentalize inclusive national identities or sectarian ones will depend on such factors as the 
intensity of the struggle for power, with sect appearing a "ready-made" tie easily instrumentalized in crises; the size of the arena of struggle, with sectarianism facilitating the personal ties crucial in small group arenas and more inclusive identities advantaged in the larger public sphere. Also, (see below), which identities are encouraged by the dominant regional norms of the time will shape political entrepreneurs" calculations.

Fifth, agency also operates at the level of regional geopolitical struggles in MENA where the identities and norms that rival states instrumentalize can powerfully impact on the "domestic" identity of highly permeable MENA states. Supra-state identities, in good part constructed by rival regional powers, have established quite different regional norms. Thus, Egypt's promotion of Pan-Arabism in the 1950s-60s delegitimized the instrumentalization of "traditional" divisive identities such as sectarianism and tribalism, which therefore had low salience. Iran's export of revolutionary Pan-Islam in the 1980s, although explicitly anti-sectarian, nevertheless introduced a religious dimension into regional identity that paved the way for sectarianism. In the post Arab Uprising period, the instrumentalization by two religiously-legitimated powers, Saudi Arabia and Iran, of Sunni-Shia enmity has been decisive in spreading sectarianism, with their rivalry stimulated by structural factors, particularly the opening of new arenas of contestation in failing states (Gause 2014).

In summary, the identity pattern of a society is a composite of social structure-the distribution of sectarian groups within society and how these are cross-cut, particularly by class; and the power of broader identities, such as nationalism, which may subsume sectarianism. These factors themselves will be altered by modernization and by how the agency of political entrepreneurs, domestic and regional, affect the distribution of kinds (intensities) of sectarianism. Together they shape the salience of sectarianism in the overall identity pattern of a society, and hence where the latter is located along a continuum from more inclusionary and universalistic to more exclusionary or particularistic: the more sectarianism is salient, the less likely a society's identity pattern will be at the inclusionary end of the continuum, with consequences, explored below, for governance.

\section{Identity patterns' consequences for governance}


Sectarianism has, however, no uniform impact on governance: in the Levant alone sectarian diverse societies have coexisted with various kinds of authoritarianism (populist and post-populist) and of democracy (majoritarian and consociational), as well as episodes of state failure. Nevertheless, the location of identity patterns along the particularism/exclusionary vs. universalistic/inclusionary continuum may make any given pattern of governance more or less likely. Here the point can only be briefly illustrated by indicating certain representative historical or theoretical possibilities.

Starting from Rostow's argument that inclusive institutions (democracy) are facilitated by inclusive identities, we can imagine a continuum. At one end, more inclusive identities, such as civic territorial-based nationalism, are most likely to facilitate majoritarian democratization (with sectarianism assumed to remain banal, hence political majorities/minorities not fixed by the demographic distribution of sectarian groups). At a mid-point, secular Arab ethno-nationalism could, in the many Arab states with large Arabic-speaking majorities, integrate sectarian (although not ethnic) minorities and thereby facilitate majoritarian democracy. In practice, however, Arab nationalism is historically associated with populist (i.e. more inclusive) forms of authoritarianism following assimilationist strategies toward minorities in which the shared Arabic language is promoted as the basis of community, subsuming sub-state sectarian identities. Somewhat further along the continuum, instrumental sectarianism is also compatible with quite different outcomes, consociational democracies (perhaps necessary when polarized identity groups are balanced in population and mobilization as in Lebanon), but also is historically associated with the divide and rule strategies of more exclusionary authoritarian regimes. At the exclusionary end of the identity continuum, militant sectarianism, if widely held, is more likely to produce violent conflict, (with religious conflicts, according to Tott (2007), more destructive and enduring than other identity conflicts), possibly resulting in civil war and state failure, or else totalitarianism (as in the "Islamic State").

\section{How Governance affects Sectarianism}

The second part of this inquiry is: how does governance affect sectarianism? First, major differences in governance in the Historical Sociology tradition are outlined (noting their consequences for identity); then, the impact on sectarianism of variations 
in the neo-patrimonial governance that dominates MENA is considered; and, finally, how failing states may affect sectarianism is examined.

For institutionalist approaches to sectarianism (Varshney 2009: 289-91), political institutions can, depending on their design, reproduce or dilute sectarianism. In the Weberian tradition, the capacity of political institutions varies according to their concentration of power and inclusiveness; the more society becomes socially and politically mobilized, the more state capacity must match it if stability is to be maintained (Huntington 1968). Strong states--high on both dimensions--are more able to regulate group (e.g. sectarian) competition peacefully while communal conflict increases in weak states, whether low in power concentration or inclusion. The extreme case, state failure, opens the door to violent forms of conflict (Scarritt 2005; Fearon 2006;_Rorbaek, this issue).

Major differences in regime type may matter less for the dimensions of state strength than expected. For example, regarding inclusion, democracy is ostensibly designed to maximize inclusion, but in deeply divided unequal societies, it may, in practice, be limited to privileged classes or dominant communal groups. Conversely, authoritarian regimes are not wholly exclusionary since they usually include some social groups in order to exclude others, albeit in different ways: e.g., revolutionary or populist forms of authoritarianism seek to mobilize broad coalitions against old oligarchies while post-populist ones include privileged upper strata in order to exclude lower strata (Hinnebusch 2010). Moreover, in MENA certain common power building practices, those of "neo-patrimonialism," cut across regime type: as such, variations within it arguably matter most. 5

\section{Neo-patrimonial regime building and its variations:}

In MENA, the master regime building strategy (as elaborated by Weber and his disciples, building on Ibn Khaldoun) is "neo-patrimonialism," a hybrid of patrimonial and bureaucratic authority. Personal authority derives from empowering those most loyal to and trusted by the ruler, often, in multi-sectarian societies, those of his family and sect; communal solidarity (assabiyya) may be instrumentalized to constitute an elite core holding the most critical (security) command posts of the state. Bureaucratic

\footnotetext{
${ }^{5}$ Although MENA's monarchies are neo-patrimonial and democracies have features of it, the focus of this paper is the authoritarian republics.
} 
authority, which depends on state institutions-civil administration, professional army, legislatures and party systems--is more inclusive since recruitment is by merit, parties incorporate activists and parliaments co-opt constituents.

However neo-patrimonialism varies in the relative balance of patrimonial vs. bureaucratic authority in any given regime: the more patrimonial the regime, the more likely elites will instrumentalize sectarianism (and other sub-state identities) at the expense of bureaucratic rationality and inclusiveness--including via sectarian recruitment of military/security forces, encouraging inter-sectarian conflict to divide and rule; and posing as protector or champion of one sect against another. If the state controls a large proportion of resources accessed via clientele connections, sectarianism may be instrumentalized as wasta or even as assabiya to bind groups seeking to monopolize power, as in Ibn Khaldoun's classic scenario. These practices foster sectarian consciousness and enervate the institutions needed to incorporate cross-class, cross-sectarian coalitions, needed if regimes are to be inclusive. However, if their bureaucratic/institutional side is sufficiently developed, neo-patrimonial regimes may deploy more inclusive strategies to deal with communal diversity. Ethnic arithmetic, accords a quota of office and patronage in order to give each group (e.g. sect) a stake in the system. But regimes may also pursue "assimilationist" strategies that aim to integrate minorities into a dominant identity, often via a single ruling party. Neopatrimonial regimes' inclusiveness has also varied according to their economic strategies between those built on a populist "social contract" in which the political loyalty of broad strata was traded for entitlements regardless of communal background, and post-populist ones that concentrate patronage resources in the hands of regimeconnected crony capitalists while excluding the lower classes. In such cases, Higashijima (2012) found that benefits also become sharply skewed among communal groups, leading to reinforcing communal and class cleavages. Inclusive institutions are weakened and the patrimonial and repressive side of regimes accentuated.

Thus, sectarianism can be both an obstacle to and an asset in the creation of power in multi-sectarian societies. In neo-patrimonial regimes the latter requires the right balance of patrimonialism--sect instrumentalized to generate elite solidarity around leaders--with bureaucratic and economic inclusion of cross sectarian coalitions. However this delicate balance is easily upset, initiating a decline into exclusivist 
versions of neo-patrimonialism, potentially opening the door to instability in which sectarianism could be inflamed.

\section{Civil war, state failure and sectarianism}

What happens to sectarianism when states fail in multi-sectarian societies? As the institutional and inclusive capacity of Arab authoritarian regimes declined and several became more vulnerable to the uprisings that swept the region after 2010 , sectarianism became more intense and salient. This was because the existential power struggles unleashed incentivized ruling elites and their opponents in multi-sectarian societies to instrumentalize sectarianism against each other: as elites did so they provoked countersectarian mobilization by oppositions (Hashemi 2015). In Yemen, Iraq and Syria the outcome was civil war and at least partial state failure

With the debilitation of institutions amidst state failure, sub-state identities, including sectarianism, may be intensified (Byman 2014; Dodge 2014) for several reasons. State failure, well described by Kaldor's (2005; 2013) “New Wars," involves the state's loss of monopoly of legitimate violence, leaving a vacuum in which remnants of state armies, paramilitaries, trans-state movements, and rival external powers contest for power. The distinction between combatants and non-combatants breaks down, generating Posen's (1993) security dilemma, wherein each communal group, seeing the other as a threat, acts pre-emptively to increase its own security-e.g. via arming, communal cleansing--in a way that makes all less secure. This may result, as Zartman (1995: 1) observes, in a "retreat" to sub-state identities: many people in multi-sectarian societies may (depending on the social structural context and the actions of political entrepreneurs) transfer their loyalties from the state to an armed sectarian group (Byman 2014). More than this, Kaldor (2013) argues, the "manufacture of fear and hatred creates new sectarian identities." The more violent the conflict, the more the perception of existential threat from the "other," the more likely these identities will take a militant sectarian form.

In turn, in a context of militant sectarianism, regimes that survived the Arab Uprising have been reconfigured as more exclusionary and coercive forms of neopatrimonialism since, once sectarian violence takes hold, the cross-sectarian coalitions needed for inclusive forms cannot readily be reconstructed and regimes must therefore depend much more on coercion and assabiyeh to survive. The result has been, 
Heydemann notes (2013), the emergence of new "harder" versions of authoritarianism than their pre-uprising predecessors. Similarly, among the opposition, violence marginalizes moderates and empowers armed militant sectarian groups seeking to establish fundamentalist, exclusivist, even totalitarian, regimes. These, in turn, could be expected to further foster sectarianism.

\section{Framework of Analysis: Toward Understanding the Interaction of Sectarianism And Governance}

The literature exposes the high complexity of the factors that explain the interaction of sectarianism and governance. Still, on the basis of this work, several clusters of variables can be identified that, together, help us to explore the impact of each on the other:

1): Long-term Identity Pattern: the enduring identity pattern of multi-sectarian societies is constituted by relative constants such as the social structure-the polarization of sectarian groups, plus class structure (whether it reinforces or crosscuts the former); and the existence (or not) of alternative more inclusive identities, with these changing only incrementally over the long term owing to modernization, as it may, e.g. broaden identities beyond sect or generate class cleavages crosscutting sectarian identities, thereby affecting the salience of sectarianism.

2) Agency: The political strategies of political entrepreneurs (including state elites, opposition movements and rival states) will matter: first, whether in power struggles, they instrumentalize sectarianism or seek to subsume it in more inclusive identities; and second, whether they design more or less inclusive governing institutions, or follow various hybrid strategies. The agency of political entrepreneurs may have important short term effects on the intensity of sectarianism and institutions middle-term impacts on it.

3. Identity affects Governance: The interaction of social structural factors with agency determines the salience of sectarianism in a society, hence the likely inclusiveness of its identity pattern. The identity pattern, in turn, conditions governance trajectories: for example, at one extreme, banal sectarianism cross-cut by class cleavages and embraced by a wider national identity is most favourable to democratization and at the other extreme, bi-polarization between militant sectarian identities increases the likelihood of civil war and failed statehood. 
4. Governance affects identity: Variations in regime institutions, in turn, can foster or dilute sectarianism over the medium term; hybrid institutions such as neopatrimonialism may do both simultaneously, depending on their inclusiveness, as shaped by their balance of patrimonial and bureaucratic authority and by variations in their (populist or post-populist) economic strategies. Additionally, while strong state institutions provide the security to contain sectarianism, insecurity in weak states encourages its instrumentalization and state failure opens the door to its intensification. The identity pattern fostered by institutions will, in turn, feed back on social structure and political strategies and hence further affect regime trajectories.

\section{Case Study: Syria}

This case study selectively deploys the above framework to explore how far sectarianism explains Syria's governance trajectory and how far governance affects sectarianism. Owing to space limitations each episode will merely illustrate (without exhaustively deploying the full framework), the different roles of sectarianism under three different governance scenarios:

1) The pre-Ba'th period of failed democratization ending in a revolutionary coup. This episode shows that the historical--"primordial"--distribution of sectarian identities matters, but when social structure and agency is such that they remain banal other factors, including broader identities, have the most impact on governance trajectories.

2) The 1963-2010 period of Ba'thist authoritarianism shows that while the instrumentalization of sect was a key ingredient in regime-making, the changing inclusiveness of Ba'thist institutions and political economy strategies helps explain first the muting of and thereafter the inflaming of sectarianism.

3) The post-uprising period (2011- ), an episode of failed democratization, this time ending in civil war and partial state failure, shows that when the instrumentalization of sectarianism in intense power struggles provokes militant bipolarizing sectarianism, the result can be civil war and exclusionary sectarian governance.

The fact that, as governance changed over the periods, the salience of sectarianism increased substantially, from low, to medium to high, suggests that differences in governance--agency and institutions--carry powerful short to medium 
term impact on the salience of sectarianism. What does the historical evidence in the Syrian case tell us about this hypothesis?

\section{1946-63: From democratic failure to revolutionary coup}

Syria became independent endowed with the formal institutions of democracy and also an identity pattern that did not exclude democratic consolidation. On the one hand the new Syrian state, being widely seen as an artificial creation of imperialism, did not enjoy the strong loyalty of its citizens, many of whom embraced supra-state ideologies, such as Pan-Syrianism or Pan-Arabism. Many also remained attached to a multitude of substate minority communities, sometimes concentrated in particular areas (e.g., the Alawi and Druze mountains). Their self-governance had been to an extent institutionalized under the Ottomans and separatism was encouraged by the French mandate's divide and rule policies, such that the minorities were typically split between pro-French groups seeking separatism and factions favouring integration into the Damascuscentred state (Faruk Alli 2014; White 2007). After independence conflicts with Damascus in the Alawi and Druze areas expressed resistance to state centralization more than sectarianism, per se; however, the new generation among the minorities was, by the 1950s, embracing integration rather than separatism.

Indeed, the majority Sunni community and the sectarian minorities-themselves divided and none constituting more than around 15\% of the population-both came, especially with the spread of modern education to the rural peripheries, to embrace a secular Arab national identity, based on the shared language, that normatively constrained overt sectarianism, with individuals simultaneously holding other identities that subsumed or cross-cut sectarianism. Most politicians framed their ideologies in inclusive nationalist terms and refrained from instrumentalization of sectarianism. This identity configuration, in diluting sectarian polarization, was, in principle, compatible with majoritarian democracy. Why then did democracy fail and what role did sectarianism play in this outcome?

Although Syria's parliamentary system was dominated by the landed-mercantile oligarchy, political mobilization of the middle class was incrementally forcing open the political arena; in the mid-fifties, relatively free competitive elections enabled the inclusion of radical middle-class party elites in parliament and government. As radical parties integrated the minorities on a non-sectarian basis while also mobilizing the 
Sunni new middle class and peasantry against the Sunni-dominated landed-mercantile oligarchy, political conflicts were between class-based cross-sectarian coalitions. The Ba'th party, promoting a secular Arab identity allowing recruitment across sectarian and class lines, was the most successful of the radical parties. Sectarian minorities from peasant backgrounds were particularly attracted by its socialist ideology and its secular Arab nationalism under which the minorities were deemed equal citizens; the overlapping of sectarian and class cleavages, especially among the Alawis, made them the most radical elements within the Ba'th party, but their radicalism was expressed in socialist, not sectarian terms. However, because this mobilisation exceeded the incorporative capacity of Syria's fragile political institutions, it destabilized rather than democratized them. The oligarchy's blockage of social reform turned frustrated radical leaders to recruit from middle class army officers who began to contest the old order in a series of destabilizing coups. Eventually, the Ba'th party came to power in a military coup aiming at revolution from above (Jabbour 1987: 150-51, 336-38; Allush 1962: 567, 132-42; Salamah 1969; Heydemann 1999; Phillips 2015, Hinnebusch and Rifai 2017; Hinnebusch 1990: 49-119; Hinnebusch 2011: 15-24; Van Dusen 1975).

Thus, when sectarian identity is subsumed through cross-sectarian class based mobilization, majoritarian democracy is one possible trajectory provided liberal institutions can contain the political struggle. That the Syrian outcome was, instead, populist authoritarian rule was partly owing to intense class conflict and the politicization of the military. And the fact that the revolutionary opposition took a class, not sectarian form, itself ultimately down to substantial levels of exclusion from governing institutions on class, not sectarian grounds.

\section{The Ba'thist regime and sectarianism:}

Does authoritarianism repress or inflame sectarianism? The Syrian Ba'th experience suggests it does both under different conditions.

The Ba'th's struggle for power started to politicize formerly banal sectarian identities. A power struggle inside the Ba'th (1963-6) was over ideological differences but rivals sought support by relying on sectarian ties (as well as other sub-state affinities such as regional origins). Within the small intra-elite arena, the closer-knit minorities were better able to instrumentalize such ties than the regionally-divided Sunni Muslim Ba'thists, who tended to lose out in power struggles, increasing the 
minority composition of the regime elite. The conflict between the Ba'th and leading Sunni-dominated opposition groups, the Nasserites and the Muslim Brotherhood, also aroused opposition to the disproportionate role of minorities in the Ba'th leadership (Van Dam 1981, al-Jundi 1969: 120-139; Salamah 1969: 29-47; Razzaz 1967: 111-140, 120-186; Seymour 1970).

Neo-Patrimonial Political Institutions: the Ba'th regime was institutionalized under Hafiz al-Asad as a populist version of neo-patrimonialism that both exploited sectarianism yet involved, as well, counter-measures that diluted it. The president appointed trusted co-sectarians to command of elite army units and the security forces. Also, however, senior Sunni politicos and military officers in his inner circle, while not having independent bases of their own, nevertheless incorporated their own clientele networks into the regime; Alawi officers also had Sunni business partners, as part of a "military-mercantile complex" centred on Damascus as, in the 1970s, Hafiz used economic liberalization to co-opt leading elements of the Damascene merchant class. "Sectarian arithmetic" ensured representation of all sectarian groups in the party politburo and council of ministers. At the base, the cross-sectarian rural constituency that the Ba'th party had mobilized in the 1950s was incorporated and expanded, with the party penetrating and co-opting Sunni as well a minority peasantry, particularly land reform peasants. The populist social contract traded political loyalty for benefits, regardless of sectarian affiliation: free higher education and government jobs for the salaried middle class; job security for industrial workers; land for peasants; subsidized food for the urban masses and considerable upward mobility for rurals of all sects. The Ba'th deployed Pan-Arab identity to legitimize itself--as the defender of the Arabs against Zionism and imperialism. It incorporated about half the population (e.g. minorities, state employed middle class, land reform peasants, the Damascene Sunni bourgeoisie).

The salience of sectarianism increased during the Muslim Brotherhood insurgency (1978-82) which was explicitly framed as a Sunni movement against heretical ruling minorities that appealed to those excluded from the regime coalition, e.g. small urban merchants and ulama; however, the Brotherhood message remained largely urban in appeal since agrarian reforms kept most Sunni peasants incorporated into the Ba'th constituency. The regime thus relied on sectarian ties to maintain its own cohesion but was cross-sectarian enough to exploit urban-rural cleavages, thus prevent 
mobilization of a Sunni majority against it (Phillips 2015; Hinnebusch 2011: 47-88, 93103; Hinnebusch 1990: 144-275).

Debilitation of the cross-sectarian coalition: Hafiz's regime had depended on the availability of considerable rent to sustain populist inclusion and when, under his son, Bashar as-Asad, it declined, the regime sought to attract investors through neo-liberal policies. In the process, it evolved into a post-populist version of authoritarianism that was more vulnerable to sectarian conflict. First, concentrating power in Bashar's hands meant pushing his father's old Sunni barons out of power, losing with them their Sunni clientele networks. Second, the concentration of the new business opportunities from the neo-liberal opening to private/Arab capital in the hands of the presidential family, especially the president's cousin, Rami Makhlouf, alienated many of the former Sunni business clients of the regime and gave the impression of enhanced Alawi dominance of the power structure (Hinnebusch 2011; Phillips 2015). Third, the running down of the welfare state and cutting of food and fuel subsidies and agricultural prices, combined with devastating drought, cost the regime the support of big parts of its peasant and lower class constituencies (Ababsa 2010; Matar 2016; Ruiz de Elvira and Zintl 2014). While the patrimonial core of the regime became more sectarian, the societal penetration of regime institutions, such as the party, contracted and the concentration of patronage in fewer hands shrunk their co-optative capacity. As resources became sharply skewed in the hands of a few regime insiders and clients, while others experienced downward pressure on their living standards, the regime was seen to renege on the social contract, and many of the losers came to see sectarian discrimination at work: for example rumours spread that Alawi teachers were taking the jobs of Sunnis in Raqqa and Hassakah, where the regime was failing to address the devastation of the great drought of 2008-10. Symptomatic of popular resentment of Alawi crony capitalists was the 2011 attack by Dera protestors on the offices of Rami Makhlouf's telecom firm. At the same time, the regime's encouragement of apparently non-political Islam had enabled the spread of Islamism beyond its former concentration in the cities into the countryside where it prepared the ideological ground for rural based Islamist insurrection (Khatib 2018). The shift in the balance between patrimonial and bureaucratic authority, shrinking inclusiveness, prepared the way for the revival of overt sectarianism in the power struggles that followed the Uprising (Hinnebusch and Zintl 2015). 
From failed democratization to failing state:

The Syrian uprising was initially not predominately about sectarianism and cannot be seen as a mere revival of "ancient hatreds," although it later became overtly "sectarianized" (Abboud 2016: 183-86). Rather, its roots were in the class disparities generated under the retreat from populism to crony capitalism (Donati, 2013; Lawson 2018; Nasser et al 2013). Moreover, initial protests, spearheaded by educated urban youth, often of rural cross-sectarian origins, were non-violent, calling for a democratic civic state and making cross-sectarian appeals (Rifai, 2018); thus, there existed the potential for a cross-sect, cross-class coalition against a non-inclusive regime that could deliver democratic reform.

The mass protests that rocked Syria, with demonstrators taking over the streets in many towns and cities, could have precipitated a pact between soft-liners in the opposition and in the regime to agree on a peaceful transition toward democracy. There were indeed soft-liners in the regime and, tellingly, they were mostly Sunni-the Tlas brothers, Vice President Farouk al-Sharaa-(but not all, since the Alawi chief of staff, General Ali Habib, opposed the use of the army against protestors), while the hardliners-e.g. the president's brother, Mahar al-Asad, were mostly Alawis, indicative of some sectarian polarization within the senior Ba'thist elite. The President may have had enough popular legitimacy to have initiated a democratic transition (Wieland 2012; Lesch 2018) but he opted to join the hard-liners and marginalize the soft-liners, a choice that shaped the whole subsequent evolution of the Syrian Uprising. Whether he actually had any other viable option is debatable: for the regime, democratization was very threatening since, having sacrificed its own cross-sectarian, cross-class base, it faced the prospect of a reinforcing sect/class mobilization against it in which Sunnis and the victims of crony capitalism would combine against Alawi-centred crony capitalism.

The regime chose instead to instrumentalize sectarianism, depicting the protestors as jihadists and itself as defender of order, secularism, and the minorities in order to rally its minority and bourgeois base, which indeed became more alarmed as the uprising was radicalized. Indeed, the opposition, while driven by socio-economic grievances, had also a sectarian dimension, inflamed by the use of Alawi recruited military units and militias to repress protests concentrated in majority Sunnis areas (Balanche 2018; ICG 2012a). The main occasion for mobilization became Friday prayers, 
in which anti-regime imams, Saudi-financed salafists and Muslim Brotherhood connected elements played a role. The Uprising took hold in mixed Sunni-Alawi neighbourhoods, such as Homs, and in traditional bastions of anti-regime Sunnism, such as Hama and Deir az-Zur, while minority-dominated areas remained quiescent (Hinnebusch 2012; Bartolomei 2018; Balanche 2018).

Once the potential pacted democratic transition failed, it was possible, given the some overlap of (lower) class and (Sunni) sectarian grievances and the continuing mass scale of protests that flooded city streets outside of Damascus and Aleppo, that a relatively peaceful revolution from below might triumph; and, once the uprising became militarized, that violent revolution would overthrow the regime. Indeed, by 2012 many outsiders believed the regime was on the ropes; why were they wrong?

Peaceful revolution required a split in the regime (and the army), combined with bandwagoning of much of society against it, as happened in Tunisia and Egypt. However, neo-patrimonial regimes like Syria, where the elite is united by sectarian ties (as well as material interests) around a patrimonial leader, are less vulnerable to elite fracture (Schmidt 2018, Said 2018); and, the army remaining largely loyal, the regime retained the coercive and co-optative capabilities to contain anti-regime mobilization. Bandwagoning mobilization against the regime required a cross-class (middle-lower class) coalition forged around intense widely shared grievances. In Syria, while many were aggrieved by Bashar's policies, others had welcomed and benefited from them (Lawson 2018). Importantly, anti-regime mobilization on class grounds was crosscut by communal (sectarian and ethnic) cleavages: the deprived classes were divided on communal lines and the majority Sunni community on class lines (Balanche 2018: 8-30). The regime demonized the opposition as jihadists (Bartolomei 2018) to sustain its coalition of minorities, the secular middle class and bourgeois Sunnis. Indicative of this, a survey of 2000 Syrian refugees in Lebanon found only 1 person of sectarian minority background backed the opposition, while Sunnis were 2 to 1 in favour of it; yet the majority of government supporters were still Sunni, mostly among the more well educated, well-off and secular (Corstange 2016). Mass protest may force peaceful democratization in more homogeneous societies where the pressure of the united people can cause regime fracture; but it is less likely where the regime is united, partially by sectarian asabiyya, and the people divided by sectarian (as well as other) differences. 
Once militarization of the conflict took hold it led not to revolution but to what Phillips (2015) called "semi-sectarian civil war" because the fighting was partially along sectarian lines. Increased regime violence stimulated defections from the army: not being of whole units, it did not threaten the regime core, but enough individual defections, combined with the external provision of safe havens (in Turkey) and external arming, enabled the construction of the opposition "Free Syrian Army (FSA)." While many senior and middle rank Sunni officers remained loyal to the regime, the vast majority of the defectors who joined the FSA were Sunni, giving the conflict a greater sectarian dimension. At the same time, the incremental depletion of the regime's military manpower, being over-dependent on minority communities, debilitated its capacity to secure territory. As the regime lost its monopoly of violence, it gradually withdrew from the east of the country leaving much of the grain growing areas and oil resources to opposition factions, mostly jihadists such as IS, but also including the Kurds who were on a separate tangent.

With increasing militarization of the conflict, the educated middle class who had promoted a civic identity were marginalized between regime violence and the mobilization of undereducated, unemployed rural youth highly susceptible to a simple salafist sectarian message (Eido 2018). Violence drove the jihadization of the opposition and this, together with the trans-state movement of non-Syrian militants into Syria, empowered jihadist groups like Jabhat al-Nusra and Ahrar ash-Sham whose fighting prowess put the regime on the defensive. Thus, civil war led to identity transformation toward a militant_jihadist_sectarianism among many activists and army deserters turned Islamist fighters. This shifted the opposition centre of gravity to hardliners whose sectarian rhetoric and violence solidified support for the regime among the minorities, state employees and crony capitalists (Goldsmith 2018; Kastrinou 2018; Rifai, 2018 Bartolomei 2018). The intervention of Sunni powers in the conflict on the side of the Sunni opposition and of Iran and Shia militias on the regime side--“a proxy conflict organized along ethno-sectarian lines" as Heydemann (2013) put it--combined with sectarian discourse in the regional media, amplified sectarian representations of the conflict that were widely embraced in society (Lynch 2015; Pierret 2013; Phillips 2016).

Finally, with the descent into civil war, the security dilemma kicked in, leading all to seek protection via local defense militias and sectarian cleansing in some 
neighbourhoods (Phillips 2015). On the opposition side, FSA units, often defectors from the regular army, formed to protect protestors from regime violence and later to defend their locales from generalized insecurity; and the regime, as the army bled manpower, encouraged the formation of local militias by its own supporters. The result was what Abboud (2016:85-86) called the civilianization of the conflict, in which the distinction between combatants and non-combatants became blurred, increasing the scope of violence, hence fear of the-increasingly sectarian-“Other" (Ali 2015; Balanche 2018, 3, 9; Rifai 2018; Leenders 2015: 252-55; Abboud 2016: 97-108, 162-87). This was accelerated by the breakdown, in many areas, of the normal economy; in its place, many people sought survival through looting and spoils or joined armed bands led by local warlords competing to tax economic flows and take cuts of external resources (Abboud 2014, Yaziji 2014, Turkmani 2015). Typically, the sectarian "other" became the target of such predators; thus, famously, markets in Alawi areas sold looted material from Sunni neighbourhoods (Rifai 2018). Both sides, seeing the war as an existential struggle, pursued a "sectarian dehumanization strategy" depicting their enemies as infidels, images systematically propagated to populations (Zelin and Borow 2014). Thus, whether intended or not, sectarian instrumentalization spread sectarian fears, discourses and behaviour to the grassroots level where they assumed a self-sustaining logic. As the country was bifurcated, the battle map between regime and opposition corresponded, to some extent, to sectarian divisions. Opposition strongholds were overwhelmingly Sunni and the targets of forced de-population at regime hands; regimecontrolled areas remained multi-sectarian as both minorities fleeing jihadists and Sunnis fleeing the fighting concentrated there (Heydemann 2013; Balanche 2018; 3). This new structure sharply constrained the possibilities of non-sectarian agency.

Governance under sectarian surge and state failure: competitive exclusivist regime formation

With the division of the country into regime and opposition controlled areas, a dynamic that could be called "competitive regime formation" emerged, with each side trying to assert its right to rule. The main competing regimes-in-formation were more coercive and less inclusive than the pre-uprising regime had been; their conflict in many ways institutionalized sectarian conflict in the Syrian space.

The Asad regime adapted to civil war by adopting a more violent, exclusivist and de-centralized form of neo-patrimonialism. The reconfigured regime centre--the Asad 
family, the security services, elite army units-represented a contraction of the top elite to its coercive-and sectarian--core. All those who had advocated compromise or power-sharing with the opposition, mostly Sunnis, such as former Vice President alSharaa, were expelled from the elite. This core rested on several pillars. The Alawi sect was absorbed en-mass into the army, security apparatus, and state, with some 500,000 living in Alawi suburbs of Damascus; implicated in the regime's crimes, suffering high casualties, facing an existential threat if the regime collapsed, they were the main loyalist base, potentially disaffected only when the regime failed to effectively protect them from the jihadist threat. Overlapping with these, but extending to Sunni figures as well, were the regime-connected crony capitalists, many of them war-profiteers. The regular army was downsized with manpower shortages and became more minoritarian, although it still incorporated Sunnis who had enjoyed upward mobility through military careers, identified with the army and lived in their own military communities (Said 2017; Khaddour 2015a). The regime also took pains to preserve the "state" bureaucracy (salaries, services), delivering scarce resources (bread, fuel); but with the contraction of state revenue, the distribution function waned and state jobs and reconstruction funding were reserved for loyalists, notably minorities (Khaddour 2015b). The decline of the army and bureaucracy led to a decentralization of power. As the regular army contracted and conscription reached a ceiling, local militias filled the gap, allowing proregime communities to assume the burden of their own self-defence; informal client networks headed by businessmen-patrons or sectarian groups set up militias selffinanced through protection rackets, extortion and pillage. To some extent, regime controlled areas were fragmenting into semi-autonomous often-sectarian fiefdoms. The resulting centre-periphery relations became more matters of personal loyalties and bargaining than bureaucratic command, contracting the regime's infrastructural power (Carter Center 2013). It tried to counter the fragmentation of armed groups through their incorporation into the National Defense Forces (NDF) but these militias still often remained immune to command from above; for example, Alawi militias obstructed a number of attempted reconciliation deals with opposition (Sunni) towns. The intimate interweaving with these of Hizbollah, Iranian forces and Shia Iraqi militias added to the loosening of control by the regime centre and the enhanced sectarian composition of this "post-Ba'thist “ regime (ICG 2013; Lund 2015; Samaha 2017). 
Jihadist and Islamist Counter States. The most effective counters to the regime were the armed Sunni Islamist movements, recruiting through jihadist ideology and extreme sectarian discourse, but also with certain bureaucratic capabilities. While Islamic State (IS) and Jahbat al-Nusra were the most radical--and effective--the differences in doctrine and practices between them and the likes of Ahrar ash-Sham was only a matter of degree. Their recruitment pool was the vast Sunni underclass that was subjected to regime violence and saw itself fighting for survival or without any economic alternative to employment as fighters and mobilized on sectarian grounds. These movements, like the regime, totally eschewed political compromise. Their powerbuilding practices were broadly similar--charismatic authoritarian leadership effective in mobilizing activist followers; yet exclusionary of all those who did not accept their visions of Islam (and backed by external support and their command of the war economy, e.g., oil wells) (ICG 2012b; Abboud 2016: 171-78; Lund 2013; Shishani 2012).

Pluralist Variants? Sectarian discourse and violence was instrumental in squeezing out non-sectarian civil society actors. The local coordinating committees that organized the initial anti-regime protests, with discourses of Syrian civil identity based on common citizenship, were marginalized by sectarian violence and the large-scale exit from Syria of secularists. Some survived in local interstices between the regime and jihadists, usually in hybrid forms, wherein elements of Islamist militias and sharia courts shared power with elected councils of more secular-minded activists, who however now deferred to Islamist discourses, and traditional notables (ulama, tribal leaders) (Khalaf 2015; Favier 2016). Compared to the main warring sides, the nonjihadi opposition, starved of resources and fragmented, failed to create governance structures that could constitute an alternative regime. It was either Islamized, criminalized or subjected to regime violence (barrel bombs, food sieges). In parallel, its natural coercive arm, the fragmented units of the Free Syrian Army, descended into warlordism, turned jihadist or were recruited as mercenaries by foreign states (Abboud 2016: 87-97). Thus, sectarianization of the conflict tended to polarize society, drowning out the civil discourse via which the uprising had initially been promoted. This led to more sectarianized forms of governance which, in turn, further promoted sectarianism.

\section{Conclusion:}


The impact of sectarianism on regime trajectories and vica versa varies sharply in different contexts as the preceding analysis has tried to expose. Here the argument is summarized, with reference to the Syria case and put in the context of the classic debates over identity politics.

Sectarian identities are not arbitrary inventions for, as "primordialists" argue, they have deep historical roots and their demographic distribution is a constant across contemporary Syrian history; this, together with the early emergence of cross-cutting class cleavages and a strong supra-state Arabism, made for a fairly stable identity pattern from the time of independence. Yet the intensity, relative salience and political role of sectarianism varied widely under different governance scenarios, from relatively unpoliticized banal sectarianism, to instrumentalization in power competitions to violent militant mobilization, and their variation, in turn, greatly affected governance. These variations, as instrumentalists believe, were, in most immediate terms, a result of how identities were instrumentalized in power struggles by rivals and how this, in turn, affected the design of institutions. But whether such instrumentalization succeeds and how it affects governance trajectories is affected by the existing identity patterns at the societal level.

To illustrate, in the post-independence liberal era societal structure mattered in that Syria's sectarian configuration-a large majority and many small minorities all seeking integration into a common secular Arab identity with horizontal and vertical cleavages crosscutting each other--kept sectarianism banal and increasingly blunted the possibilities of sectarian mobilization. The ascendance of broader identities such as Arab nationalism was enabled by modernization-notably the spread of secular education to the rural areas--making possible the mobilization of opposition movements via inclusive Arabism rather than sectarianism. This context was compatible with both majoritarian democratization and the revolutionary coup that actually resulted; what decided among these possibilities was the mobilization of class identities, a function of social modernization, as modernist approaches to identity would expect. Thus, in this scenario sectarianism remained of low salience since political entreprenuers refrained from instrumentalizing it; but because institutions were insufficiently inclusive on class (not sectarian) grounds, anti-regime mobilization took a revolutionary class, not a sectarian form, leading to democratic breakdown. 
The power struggles unleashed by the Ba'thist coup incentivized the instrumentalization of sectarianism in both intra-regime and regime-opposition conflicts. The successful consolidation of Ba'thist authoritarianism shows the utility of manipulating sectarian ties in power struggles. But whether the resulting regime institutions, in turn, foster or mute sectarianism depends on their inclusiveness. Hafiz al-Asad's populist authoritarianism contained sectarianism through partially-inclusive institutions and a re-distributive social contract incorporating a cross-sectarian, crossclass coalition that kept sectarian salience at a medium level (normally low but with periodic episodes of high salience); the neo-liberal post-populist authoritarianism under his son, Bashar, produced a more exclusionary regime with declining institutional capacity, that revived sectarian identities and also class grievances. Thus, under Ba'thist authoritarian rule, sectarianism started out of medium salience, from its instrumentalization in both consolidation of the Ba'thist regime and by the latter's opponents, but it was diluted by relatively inclusive institutions; once inclusiveness declined both sectarian and class grievances escalated, and since these reinforced each other among those excluded, sectarian salience reached medium to high levels by 2010.

Once institutions are debilitated, what identities rival choose to instrumentalize will matter but, again, outcomes will be affected by the inherited identity pattern and social structure. Thus, while the activists of the Syrian uprising initially used the discourse of civic nationalism to mobilize the cross-sectarian/cross class coalition needed for the democratization many wanted, social structure-cross-cutting cleavages--was stacked against the massive bandwagoning needed to bring about such regime change: while society tended to split along both sectarian and class lines, the regime's sectarian assabiyeh helped its core remain cohesive.

As the uprising proceeded, the regime's instrumentalization of sectarianism provoked counter-sectarianization in the opposition that tipped the country into civil war, militarization, and insecurity, bi-polarizing grassroots identity. The exploitation of militant sectarianism by both regime and opposition, followed by partial state failure, propelled a high level of sectarian salience, which led to declining institutional inclusiveness in both regime and counter-regime governance, further stimulating militant sectarianism.

The Syrian case suggests-and it may have wider relevance-that social structure and identity pattern, e.g.-the distribution of sectarian groups, cross-cutting 
cleavages, rival identities-may, at the time of regime formation, make some institutional trajectories more likely than others. However, given that these factors changed only incrementally over the periods surveyed, the change in sectarianism in Syria from low to high intensity seems down to politics: agency and institutional design-even if social structural constants did affect which strategies were possible or effective for contesting agents at given junctures.

\section{References}

Ababsa, Myriam (2015), "The End of a World: Drought and Agrarian Transformation in Northeast Syria 2007-2010, in R Hinnebusch and T. Zintl, Syria from Reform to revolt, Volume 1: political economy and International Relations, Syracuse, NY: Syracuse University Press.

Abboud, Samer (2014), “Syria's War Economy,” Carnegie Middle East Center, 9 January, http://carnegieendowment.org/syriaincrisis/?fa $=54131$

Abboud, Samer (2016), Syria, Cambridge UK: Polity.

Ali, Ali Abdul Kadir (2015) "The Security Gap in Syria: Individual and Collective Security in '

Rebel-held_Territories," Stability: International Journal of Security \& Development, 4(1), pp. 1-20

Allush, Naji (1962), al-Thawra wal-Jamahir [The revolution and the masses], Beirut: Dar al-Talia

Balanche, Fabrice (2018) Sectarianism in Syria's Civil War, Washington DC: Washington Institute for Near East Policy.

Bartolomei, Enrico (2018) "Sectarianism and the battle of narratives in the context of the Syrian Uprising, in ed. Hinnebusch and Imadi, The Syrian Uprising, pp. 223-41. 
Brubaker, Roger (2015), "Religious Dimensions of Conflict and Violence, " Sociological Theory, 33:1, 1-19.

Byman, Daniel (2014), 'Sectarianism Afflicts the New Middle East,' Survival, 56:1.

Carter Center, (2013) “Syria: Pro-Government Paramilitary Forces,” November 5.

Corstange, David (2016) "What Syrian Want, New Survey Data Shows which sides refugees support, " Foreign Affairs, September 14.

Deutsch, Karl, (1961) "Social Mobilization and Political Development," American Political Science Review, 55: 3, pp. 493-514

Dodge, Toby (2014), "Seeking to explain the rise of sectarianism in the Middle East: The case study of Iraq," Project on Middle East Political Science, http://pomeps.org/2014/03/19/seeking-to-explain-the-rise-of-sectarianism-in-themiddle-east-the-case-study-of-iraq/

Donati, Caroline (2013), "The Economics of Authoritarian Upgrading in Syria," In Middle East Authoritarianisms, eds. Steven Heydemann and Reinoud Leenders, Stanford CA: Stanford University Press, pp.

Eido, Isam (2018) “The Rise of Sunni Salafism" in eds., Hinnebusch and Imady, The Syrian Uprising, pp. 260-70.

Farouk-Alli, Aslam (2014), "Sectarianism in Alawi Syria: Exploring the Paradoxes of Politics and Religion," Journal of Muslim Minority Affairs, 34:3, 207-26.

Favier, Agnes (2016), "Local Governance dynamics in opposition controlled areas in Syria," pp. 6-15, in Luige Narbone, Agnes Favier, Virginie Collombier, Inside Wars: local dynamics in Syria and Libya, Florence: European University Institute 
Fearon, James D. 2006. 'Ethnic Mobilization and Ethnic Violence. In The Oxford Handbook of Political Economy, eds. Weingast, Barry R. and Donald A. Wittman. Oxford: Oxford University Press, 852-68.

Gause, F Gregory III (2014) "Beyond Sectarianism: the New Middle East Cold War," Brookings Doha Center Analysis Paper, July.

Gerring, John; Dominic Zarecki and Michael Hoffman (2016) "The Diverse Effects of Diversity on Democracy," British Journal of Political Science, 48(2), 283-314

Goldsmith, Leon, (2018), “Syria's Alawis: Structure, perception and agency in the Syrian Uprising in ed Hinnebusch and Imady, The Syrian Uprising, pp.41-58

Grove, D. John (1987) “A Cross-national Examination of cross-cutting and reinforcing cultural cleavages," International Journal of Comparative Sociology, 28:3-4.

Gubler Joshua R. and Joel Sawat Selway. (2012) "Horizontal Inequality, Crosscutting Cleavages, and Civil War," Journal of Conflict Resolution. 56: 2, 206-232.

Haddad, Fanar (2011), Sectarianism in Iraq, London: Hurst, pp. 1-29.

Hashemi, Nadar (2015) "Toward a Political Theory of Sectarianism in the Middle East: The Salience of Authoritarianism over Theology," Middle East Institute October 27, http://www.mei.edu/content/map/toward-political-theory-sectarianism-middle-eastsalience-authoritarianism-over-theology

Heydemann, Steven (1999)_Authoritarianism in Syria: Institutions and Social Conflict, 1946-1970, Cornell NY: Cornell University Press.

Heydemann, Steven (2013). "Syria and the Future of Authoritarianism," Journal of Democracy, 24: 4, pp. 59-73. 
Higashijima, Masaaki (2012), "Multiethnic Autocracy under Economic Globalization: Theory and Evidence from Developing Countries" (August 27), APSA 2012 Annual Meeting Paper. Available at SSRN: https://ssrn.com/abstract=2110184

Hinnebusch, Raymond (1990), Authoritarian Power and State Formation in Ba 'thist Syria: Army, Party and Peasant, Westview Press.

Hinnebusch, Raymond (2011) Suriya: thawra min fauq [Syria: revolution from above], Beirut: Riad al-Rayyes Books.

Hinnebusch, Raymond (2010) "Toward a Historical Sociology of State Formation in the Middle East," Middle East Critique, 19:3, Fall.

Hinnebusch, Raymond (2011), “The Ba'th Party in Post-Ba'thist Syria: President, Party and the Struggle for 'Reform' Middle East Critique , 20: 2.

Hinnebusch, Raymond (2012), "Syria: from Authoritarian Upgrading to Revolution?" International Affairs, January.

Hinnebusch Raymond and Tina Zintl (2015), “The Syrian Uprising and Bashar al-Asad's First Decade in Power," in Hinnebusch and Zintl, eds., Syria: From Reform to Revolt: volume 1: Politics and International relations, Syracuse, NY: Syracuse University Press, 285-310.

Hinnebusch, Raymond and Ola Rifai (2017), "Syria: Identity, State formation and Citizenship," in N Butenschon and Meijer, ed. Arab Citizenship in the New Political Era (Leiden, Brill) pp. 105-128.

Hinnebusch, Raymond and Omar Imady (2018) The Syrian Uprising: Domestic Origins and Early Trajectory, London and New York: Routledge.

Huntington, Samuel (1968) Political Order in Changing Societies, New Haven: Yale University Press. 
International Crisis Group (ICG) (2012a), "Syria's Mutating Conflict,” Middle East Report, 128, August 1.

ICG (2012b), “Tentative Jihad, Syria's Fundamentalist Opposition,” Middle East Report, 121, October 12 .

ICG (2013) “Syria's Metastasising Conflicts,” Middle East Report, 143, 27 June,

Jabbur, George (1978) al-Fikra al-Siyasi al-mu'asir fi Suriya [Contemporary Political Thought in Syria], Beirut: Riad al-Rayyes Books

Al-Jundi, Sami (1969), al-Ba'th, Beirut: Dar al-Nahar

Kaldor, Mary (2005) "Old Wars, Cold Wars, New Wars and the War on Terror," International Politics, 42: 491-08)

Kaldor, Mary (2013) "How to End Syria's 'new war,"” al-Jazeera, November 13. http://america.aljazeera.com/opinions/2013/11/how-to-end-syriaasnewwar.html

Kastrinou, Maria (2018), "Imperial sectarianism: and the impact of war on a Druze neighbourhood in Syria," in eds. Hinnebusch and Imady, The Syrian Uprising, pp. 271-89.

Kerr, Michael and Craig Larkin (2015), The Alawis of Syria: War, faith and Politics in the Levant, London: Hurst.

Khaddour, Kheder (2015a), "Assad's Officer Ghetto: Why the Syrian Army Remains Loyal", Carnegie Middle East Center, November 4,

Khaddour, Kheder (2015b) “The Assad Regime's Hold on the Syrian State," Carnegie Middle East Center, July 8.

Khalaf, Rana (2015), “Governance without Government in Syria: Civil Society and State Building during Conflict, Syria Studies 7: 3, 37-72, https://ojs.standrews.ac.uk/index.php/syria/article/view/1176/911 
Khatib, Line (2018), "Tutelary Authoritarianism and the shifts between secularism and Islam in Syria," in ed. Hinnebusch and Imady, The Syrian Uprising, pp.92-105

Lawson, Fred (2018), "Re-visiting the Political Economy of the Syrian Uprising, " in Hinnebusch and Imady, The Syrian Uprising, pp. 77-91.

Leenders, Reinoud (2015), “Repression is not a 'stupid thing': regime responses to the Syrian uprising and insurgency" in eds. Michael Kerr and Craig Larkin, The Alawis of Syria: War, faith and Politics in the Levant, London: Hurst, 245-73.

Lesch, David (2018), "Bashar's Fateful Decision," in eds. Hinnebusch and Imady, The Syrian Uprising, pp. 128-40.

Lund, Aron (2013) "The Non-State Militant Landscape in Syria," Combating Terrorism Center at West Point, August 27, https://ctc.usma.edu/posts/the-non-state-militantlandscape-in-syria

Lund, Aron, (2015) “Who are the pro-Asad Militias?", Carnegie Middle East Center, March 2, http://carnegie-mec.org/diwan/59215?lang=en

Lynch, Marc (2015) “The Rise and Fall of the New Arab Public Sphere," Current History, December.

Malmvig Helle (2015) "Coming in from the Cold: How we may take sectarian identity politics seriously in the Middle East without playing to the tunes of regional power elites" POMEPS Memo, August 19.

Matar, Linda (2016), The Political Economy of Investment in Syria, Basingtoke, UK: Palgrave MacMillan, pp. 13-35

Merkel, Wolfgang and Brigette Wieffen (2012), "Does Heterogeneity Hinder Democracy," Comparative Sociology 11, 387-42 
Nasser, Rabie, Zaki Mehchy and Khalid Abu Ismail (2013) "Socioeconomic Roots and Impact of the Syrian Crisis," Syrian Center for Policy Research, January.

Phillips, Christopher (2015) 'Sectarianism and conflict in Syria.' Third World Quarterly 36:2, pp. 357-376.

Phillips, Christopher (2016) The Battle for Syria: International Rivalry in the New Middle East, New Haven and London: Yale University Press.

Pierret, Thomas (2013), “The Reluctant Sectarianism of Foreign States in the Syrian Conflict," Peacebrief 162, Washington, DC: US Institute of Peace.

Posen, Barry (1993) 'The Security Dilemma and Ethnic Conflict', Survival, 35, no. 1 (Spring).

Razzaz, Munif (1967) al-Tajriba al-Murra [The Bitter Experience], Beirut: Dar alGhandur

Rifai, Ola (2018), "Sunni/Alawi Identity Clashes in the Syrian Uprising: a continuous reproduction?" in eds. Hinnebusch and Imady, The Syrian Uprising, pp. 242-59.

Ruiz de Elvira, Laura and Tina Zintl (2014), "The End of the Ba'thist Social Contract in Bashar al-Asad's Syria," in International Journal of Middle East Studies, 46:2, 329-49.

Rustow, Dankwart (1970). "Transitions to Democracy: Toward a Dynamic Model," Comparative Politics, 2: 3, pp. 337-363.

Said, Salem (2108), The Uprising and the Economic Interests of the Syrian MilitaryMercantile Complex" in eds. Hinnebusch and Imady, The Syrian Uprising, pp. 56-76.

Salamah, Ibrahim (1969) al-Ba'th min al-Madaris ila al-thakanat, [The BA'th from the School to the Barracks], Beirut. 
Salloukh, Bassel (2013), "The Arab Uprisings and the Geopolitics of the Middle East," International Spectator, 48:2.

Samaha, Nour, (2017), “Survival is Syria's Strategy, Report Syria The Century Foundation, Feb 8, https://tcf.org/content/report/survival-syrias-strategy/

Scarritt, James R, (2005), "Ethnopolitics and Nationalism," in Peter Burnell and Vicki Randall, Politics in the Developing World, Oxford University Press

Schmidt, Soren (2018), “The Power of Sultanism: why Syria's non-violent protests did not lead to a democratic transition," eds, Hinnebusch and Imady, The Syrian Uprising, pp. 30-43.

Seymour, Martin (1970), "The Dynamics of Power in Syria since the Break with Egypt", Middle Eastern Studies, 6:1, pp. 35-47.

al-Shishani, Murad Batal (2012, November): Jihad in Syria: A Profile of Jabhat al-Nusra. Terrorism Monitor, 10(22), 4-6. URL:

http://www.jamestown.org/uploads/media/TM 010 Issue22 01.pdf

Sluglett, Peter (2016) "Deadly Implications: the Rise of Sectarianism in Syria” in ed. In: Beck M., Jung D and Seeberg P. (eds) The Levant in Turmoil. The Modern Muslim World. Palgrave Macmillan, New York

Toft, Monica Duffy (2007) “Getting religion? The Puzzling Case of Islam and Civil war International Security, 31:4 spring: 97-131.

Turkmani, Rim (2015) "ISIL, JAN and the War Economy in Syria," London School of Economics, $\quad 30 \quad$ July; $\quad$ http://www.securityintransition.org/wpcontent/uploads/2015/08/ISIL-IAN-and-the-war-economy-in-Syria1.pdf

Van Dam, Nicholas (1981) The Struggle for Power in Syria: Sectarianism, Regionalism and Tribalism in Politics, 1961-80, London: Croom-Helm 
Van Dusen, Michael (1975) “Downfall of a Traditional Elite”, in F. Tachau (ed.), Political Elite and Political Development in the Middle East (Cambridge, MA: Schenkman/Wiley), 115-155.

Varshney, Ashutosh (2009), "Ethnicity and Ethnic Conflict' in Oxford Handbook of Comparative Politics, eds. Carles Boix and Susan C. Stokes, Oxford: Oxford University Press , pp. 275-94.

White, Benjamin, (2007), The Nation-State form and the emergence of "Minorities" in Syria" Studies of Ethnicity and Nationalism, 7:1, 64-85.

Wieland, Carsten (2012), Syria: A Decade of Lost Chances: Repression and Revolution from Damascus Spring to Arab Spring, Seattle: Cune Press

Yazigi, Jihad (2014), Syria's War Economy," ECFR, April.

Zartman, I William (ed), (1995) Collapsed States: The Disintegration and Reconstruction of Legitimate Authority (Boulder CO: Lynne Rienner Publishers).

Zelin, Aaron Y and Richard Borow (2014), "The Vocabulary of Sectarianism," Foreign Policy, January 29. 